\title{
Biological Activity of Lasiodiplodia pseudotheobromae IBRL OS- 64 Extracts, an Endophytic Fungus Isolated from Medicinal Herb, Ocimum sanctum Against Foodborne Diarrhea-Caused Bacteria
}

\author{
Taufiq MMJ*, Darah I
}

\section{Taufiq MMJ*, Darah I}

Industrial Biotechnology Research Laboratory, School of Biological Sciences, Universiti Sains Malaysia, 11800 Minden, Penang, MALAYSIA.

\section{Correspondence}

\section{Taufiq MMJ}

Industrial Biotechnology Research Laboratory, School of Biological Sciences, Universiti Sains Malaysia, 11800 Minden, Penang, MALAYSIA.

Phone no: +6013 4158746;

Fax: +604 6565125;

E-mail: taufiqjalil28@gmail.com

History

- Submission Date: 12-02-2020;

- Review completed: 05-03-2020;

- Accepted Date: 16-03-2020.

DOI : 10.5530/pj.2020.12.127

Article Available online http://www.phcogj.com/v12/i4

Copyright

(C) 2020 Phcogj.Com. This is an open access article distributed under the terms of the Creative Commons Attribution 4.0 International license.

\begin{abstract}
Introduction: Foodborne disease is a serious public health problem worldwide and most of the disease is related to food spoilage by bacteria. Thus, there is a need for the discovery of a natural antibiotic to inhibit these foodborne bacteria. Materials and Methods: Disk diffusion and broth microdilution assays were performed to access the antibacterial activity of the fungal extracts against test bacteria. Meanwhile, the scanning electron microscope (SEM) was employed to study the structural degeneration of bacterial cells exposed to the extracts. Results: The ethyl acetate extract of Lasiodiplodia pseudotheobromae IBRL OS64 demonstrated favorable antibacterial activity towards all test bacteria with inhibition zone ranged from $15.0 \mathrm{~mm}$ to $26.0 \mathrm{~mm}$. All test bacteria were resistant to hexane and butanolic extracts. Minimum inhibition concentration (MIC) values of the ethyl acetate extract between $62.5 \mu \mathrm{g} / \mathrm{mL}$ to $500 \mu \mathrm{g} / \mathrm{mL}$ whereas minimum bactericidal concentration (MBC) was in the range of $125 \mu \mathrm{g} / \mathrm{mL}$ to $2000 \mu \mathrm{g} / \mathrm{mL}$. The SEM micrographs exhibited major abnormalities that occurred on the bacterial cells after exposure to the extract with alteration in their morphology and cell death beyond repair. Conclusion: The extracts of L. pseudotheobromae IBRL OS-64 may be an effective antibacterial agent to treat foodborne bacteria.

Key words: Foodborne disease, Lasiodiplodia pseudotheobromae, Minimum Inhibitory Concentration, Minimum Bactericidal Concentration, Scanning electron microscope.
\end{abstract}

\section{INTRODUCTION}

Food poisoning illness occurs as a result of the consumption of foods contaminated with bacteria and this is considered as one of the most causes of sickness and death in developing countries. ${ }^{1}$ There are several symptoms regarding food poisoning illness including fever, diarrhea, vomiting, dehydration and abdominal cramps. ${ }^{2}$ Although food poisoning causes discomfort to human, it is one of condition that should not be taken for granted as it could cause death, especially when dehydration happens. ${ }^{3}$ Generally, foodborne diseases have been associated with the consumption of foods such as processed meat, beef, soft cheese, poultry, eggs and other related foods. ${ }^{4}$ Most of food poisoning reports are associated with bacterial contamination especially Gram-negative bacteria such as E. coli, P. mirabilis, ${ }^{6}$ Y. enterocolitica, ${ }^{7}$ and Gram-positive bacteria including Bacillus cereus, ${ }^{8}$ B. mojavensis and B. subtilis. ${ }^{9}$ The ability of the foodborne bacteria such as Bacillus cereus to produce emetic toxin and enterotoxins is the most important cause of foodborne poisoning. ${ }^{10}$

Nowadays, the emergence of a multidrug-resistant strain of foodborne bacteria has become a worldwide human health problem and food safety. For instance, Brunelle ${ }^{11}$ reported the multidrugresistant Salmonella enterica Serovar typhimurium isolated from clinical samples originally cultured from cattle. They found that six isolates were resistant to chloramphenicol, streptomycin, ampicillin, and tetracycline. Kiessling ${ }^{12}$ reported the multidrug-resistant phenomenon occurred due to the uncontrolled use of chemical antimicrobial preservatives that induced the appearance of more microbial strains resistant towards classics antimicrobial agents. Besides that, excessive amounts of antibiotics used for human therapy, farm animals and aquaculture industry resulted in the selection of bacterial resistance to multiple drugs. ${ }^{13}$ The bacterial multidrug resistance might be generated by two mechanisms which are the accumulation of multiple genes for resistance to a single drug in resistance (R) plasmids and expression of genes that coding multidrug efflux pumps which extruding a wide range of drugs. Besides that, consumer's demand has increased for the foods with long shelf-life but with the presence of no or minimum chemical food additives. ${ }^{14}$ Thus, there has been a growing demand among customers for natural preservatives and additives in processed foods. ${ }^{15}$ Therefore, the discovery of natural drugs and food preservatives has become popular among researchers.

Endophytic fungi are one of the well-known sources of natural products. Fungal endophytes are defined as mitosporic or meiosporic ascomycetes that asymptomatically live in the internal tissue of plants and they usually colonize the healthy and living tissue through quiescent infections. ${ }^{16}$ The mutual relationship between endophytic fungi and their hosts could impose several effects on

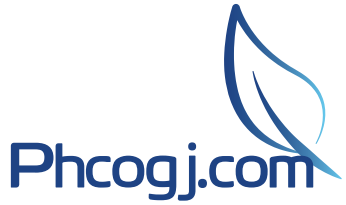

Cite this article: Taufiq MMJ, Darah I. Biological Activity of Lasiodiplodia pseudotheobromae

IBRL OS-64 Extracts, an Endophytic Fungus Isolated from Medicinal Herb, Ocimum sanctum Against Foodborne Diarrhea-Caused Bacteria. Pharmacogn J. 2020;12(4):897-904. 
the formulation of bioactive substances that can benefit humans. ${ }^{17}$ Lasiodiplodia pseudotheobromae is a member of Botryosphaeriaceae that is known to cause stem cankers, dieback and stem-end rot to crops worldwide especially mango. ${ }^{18}$ This species is reported to possess several pharmaceutical potentials including cytotoxic ${ }^{19}$ and antimicrobial ${ }^{20}$ activities. Some of its bioactive compounds are mellein, 2-phenylethanol, cyclo-(Trp-Ala), indole-3-carboxylic acid (ICA) and indole-3-carbaldehyde. ${ }^{21}$ Therefore, the current study was designed to investigate the antibacterial activity of the ethyl acetate crude extract of endophytic fungus, Lasiodiplodia pseudotheobromae IBRL OS-64 against foodborne bacteria.

\section{MATERIALS AND METHODS}

\section{Endophytic fungus culture and maintenance}

The endophytic fungus, Lasiodiplodia pseudotheobromae IBRL OS-64 was provided by the Industrial Biotechnology Research Laboratory (IBRL), School of Biological Sciences, Universiti Sains Malaysia, Penang, Malaysia. The fungal isolate was cultured and maintained on potato dextrose agar (PDA) nourished with powdered host plant (2 $\mathrm{g} / \mathrm{L}$ ) and stored at $4^{\circ} \mathrm{C}$. To ensure its purity and viability, the isolate was subcultured once a month on sterile fresh media.

\section{Test microorganisms}

The Bacillus cereus, Bacillus subtilis, Staphylococcus aureus, Escherichia coli, Yersinia enterocolitica and Acinetobacter anitratus cultures were provided by the IBRL, School of Biological Sciences, Universiti Sains Malaysia, Penang, Malaysia. The bacterial cultures were grown on nutrient agar (NA), incubated at $37^{\circ} \mathrm{C}$ for 24 hours and stored at $4^{\circ} \mathrm{C}$.

\section{Preparation of bacterial inoculum}

Bacterial inoculum was prepared by picking several single colonies from 24-h-old culture and transferred into $5.0 \mathrm{ml}$ of $0.85 \%$ sterile physiological saline $(\mathrm{w} / \mathrm{v})$. The turbidity of the bacterial suspension was adjusted to match $0.5 \mathrm{McF}$ arland standards (approximately $1 \times 10^{8}$ $\mathrm{CFU} / \mathrm{mL}$ ).

\section{Culture medium}

Yeast extract sucrose (YES) broth (Merck, Germany) supplemented with host plant water extract was used as a fermentative medium and the culture medium was prepared according to procedures described by Taufiq and Darah. ${ }^{22}$

\section{Fermentation and extraction}

Two mycelial plugs of 3-d-old of endophytic fungal culture were introduced into $250 \mathrm{~mL}$ Erlenmeyer flasks containing $100 \mathrm{~mL}$ YES broth. The cultures were then incubated at $30^{\circ} \mathrm{C}$ under a static condition in the dark for 16 days. The fermentative broth and fungal biomass were separated out using filter papers (Whatman, No.1). The filtered broth was then extracted thrice with an equal volume of ethyl acetate $(1: 1$; $\mathrm{v} / \mathrm{v})$. The upper organic phase was collected and concentrated using a rotary evaporator. The concentrated mixture was left to dryness in a fume hood to obtain ethyl acetate crude paste. The crude paste was then extracted and fractionated with different polarity solvents including hexane, dichloromethane, ethyl acetate, and butanol. Each solvent extracts were left to dryness and the paste was weighed.

\section{Disk diffusion assay}

The assay was carried out according to the method described by NCCLS. ${ }^{23}$ The fungal extracts from different solvents were dissolved in $50 \%$ methanol $(\mathrm{w} / \mathrm{v})$. Prior to that, the microbial inoculums were swabbed on the dried surface of the Muller Hinton agar (MHA) using sterile cotton swabs. An amount of $20 \mu \mathrm{L}$ of the extracts was impregnated to the sterile Whatman antibiotic disk and then placed on the surface of the previously seeded medium. Twenty percent of methanol was used as a negative control whilst chloramphenicol $(30 \mu \mathrm{g} / \mathrm{mL})$ was set as a positive control. The plates were then inversely incubated at $37^{\circ} \mathrm{C}$ for 24 hours. The diameter of the inhibition zone formed surrounding the disc was measured and recorded. The experiments were carried out in triplicates on different occasions.

\section{$\mathrm{MIC}$ and $\mathrm{MBC}$ determinations}

The MIC value of the fungal crude extract was determined using broth microdilution assay recommended by NCLLS. ${ }^{23} \mathrm{~A}$ two-fold dilution of the fungal extract was prepared in sterile Muller Hinton Broth (MHB) medium and $100 \mu \mathrm{l}$ of the extract was dispensed into each well of the microtiter plate. On the other hand, $100 \mu \mathrm{l}$ of bacterial inoculum at approximately $1 \times 10^{6} \mathrm{CFU} / \mathrm{ml}$ was added into each of the wells for a final volume of $200 \mu \mathrm{l}$ and the final concentration of bacteria in each well was $5 \times 10^{5} \mathrm{CFU} / \mathrm{ml}$. Chloramphenicol was used as a positive control and $5 \%$ methanol was set as a negative control. The MIC value was recorded as the lowest concentration of the crude extract that capable to inhibit the visible growth of test bacteria after the overnight incubation period. $\mathrm{MBC}$ value of the fungal crude extract was subsequently determined upon the reading of MIC value. An amount of $0.1 \mathrm{~mL}$ of sample in clear wells at concentrations greater than the defined MIC was streaked on a fresh MHA and the procedures were repeated for the next wells in ascending extract concentrations. The inoculated plate was incubated at $37^{\circ} \mathrm{C}$ overnight. The MBC was observed and recorded as the lowest concentration of fungal crude extract that resulted in a reduction of 99.9\% bacterial growth relative to the growth control.

\section{Scanning electron microscopy (SEM)}

Bacterial samples, fixation and dehydration process were prepared according to the method described by Taufiq and Darah. ${ }^{22}$ The mixture was then incubated at $37^{\circ} \mathrm{C}, 150 \mathrm{rpm}$ for 36 hours. At every $12 \mathrm{~h}$ of the time interval, the mixture was harvested and centrifuged to obtain the bacterial cell pellet. The pellet was then undergone the primary fixation, post-fixation and dehydration process. The dried bacterial cells were mounted on a specimen stub using conductive tape and coated with 5 $10 \mathrm{~nm}$ gold using a sputter coater machine (Fison SC-515, UK) before SEM viewing process. The specimen was then viewed under a scanning electron microscope (Leica Cambridge, S-360, UK).

\section{Statistical analysis}

All the experiments were performed in triplicate $(n=3)$ and the experimental data were expressed as mean \pm standard deviation (SD). The data were analyzed by means of the One Way ANOVA using SPSS 15.0 and Duncan test was used to access the differences between means. The results were considered statistically significant if $\mathrm{p}<0.05$.

\section{RESULTS}

\section{Antibacterial activity}

Table 1 shows the extraction yield obtained from the solvent partitioning method. From the one gram of crude paste used, $0.01 \mathrm{~g}$ of hexane extract $(0.69 \%)$ with colorless paste was obtained. Subsequently, an amount of $0.74 \mathrm{~g}$ of dichloromethane extracts which equivalent to $52.86 \%$ with brownish paste was obtained. Then, the ethyl acetate extract obtained was $0.32 \mathrm{~g}(22.86 \%)$ with beige-colored paste. Finally, $0.13 \mathrm{~g}$ of butanolic extract $(9.29 \%)$ with yellowish colored paste was obtained. As shown in Table 2, all the test bacteria were susceptible to the ethyl acetate extract with inhibition zone in the range of $15.0 \mathrm{~mm}$ to $26.0 \mathrm{~mm}$. Among Gram-positive bacteria, B. subtilis $(26.0 \pm 1.0 \mathrm{~mm})$ was more susceptible to the extract compared to B. cereus $(21.0 \pm 1.0 \mathrm{~mm})$ and $S$. aureus $(20.4 \pm 0.6 \mathrm{~mm})$. For Gram-negative bacteria, the extract exhibited higher antibacterial activity against $Y$. enterocolitica compared 
to $E$. coli and A. anitratus with an inhibition zone of $20.1 \pm 0.6 \mathrm{~mm}$. The results revealed that the Gram-positive bacteria were more susceptible compared to the Gram-negative bacteria. Besides that, all test bacteria were resistant to the dichloromethane extract except $Y$. enterocolitica with inhibition zone in the value of $8.6 \mathrm{~mm}$. This finding revealed that there might be more than a single bioactive compound in the extract that can inhibit bacterial cells. However, none of the test bacteria were susceptible to hexane and butanolic extract and this indicated that most of the bioactive compounds produced by $L$. pseudotheobromae IBRL OS-64 were mid-polar compounds since they can be extracted by midpolar solvents.

\section{MIC and MBC determination}

Table 3 shows the MIC and MBC values of the extract towards B. cereus, B. subtilis, S. aureus, E. coli, Y. enterocolitica, and A. anitratus. The antibacterial activity of the crude extract was concentration-dependent and the $\mathrm{MBC}$ values of all test bacteria were significantly higher than MIC values. The present study revealed that ethyl acetate extract was the most potential to be used as an antibacterial agent with the MIC values between 62.5 to $500 \mu \mathrm{g} / \mathrm{mL}$. On the other hand, MBC values of the extract were observed to be in the ranged between 125 to 2000 $\mu \mathrm{g} / \mathrm{mL}$. The MIC values for Gram-positive bacteria, B. cereus and $B$. subtilis were $62.5 \mu \mathrm{g} / \mathrm{mL}$ whereas for $S$. aureus was $125 \mu \mathrm{g} / \mathrm{mL}$. The MIC values for Gram-negative bacteria, A. anitratus, and E. coli were $500 \mu \mathrm{g} / \mathrm{mL}$ whilst $Y$. enterocolitica was $500 \mu \mathrm{g} / \mathrm{mL}$. The similar MBC values were observed for B. cereus and B. subtilis with a value of 125 $\mu \mathrm{g} / \mathrm{mL}$ and for $S$. aureus, the value was $250 \mu \mathrm{g} / \mathrm{mL}$. Meanwhile, the
$\mathrm{MBC}$ values for $Y$. enterocolitica, E. coli, and A. anitratus were $250 \mu \mathrm{g} /$ $\mathrm{mL}, 2000 \mu \mathrm{g} / \mathrm{mL}$ and $1000 \mu \mathrm{g} / \mathrm{mL}$, respectively. However, the Grampositive bacteria were observed to be more susceptible to the extract compared to the Gram-negative bacteria based on the MIC and MBC values. It is noteworthy that the extract exhibited a bactericidal effect against all test bacteria since the ratio of MBC/MIC was less or equal to 4 . Thus, the current study revealed that the ethyl acetate extract $L$. pseudotheobromae IBRL OS-64 might be an effective antibacterial agent to kill foodborne bacteria.

\section{Morphological changes of extract-treated cells}

Figure 1 shows the SEM micrograph of the Bacillus cereus cells after treatment at the $\mathrm{MBC}$ value. Figure 1a shows the control of bacterial cells without any treatment and it shows typical normal cells of B. cereus, with rugose and rod-shaped structure. Figure $1 \mathrm{~b}$ exhibits the bacterial cells after treated with the extract and the cells become irregular in shape and some of them were crumpled losing of their rod shape. Figure 2 shows the photomicrographs of the untreated (control) and ethyl acetate extract-treated Yersinia enterocolitica cells at MIC value. Figure 2a exhibits the normal structure of Gram-negative bacteria with rod-shape and rugose morphology. The binary fission of the bacterial cells also occurred in the control sample (indicated by black arrow). However, the bacterial cells undergo several abnormalities after treated with the extract. The formation of shrunken, distorted cells with cavities and cell debris was observed on the majority of the cells. The cavity observed on the surface of the most bacteria cells finally led to cell lysis and death beyond repair.

Table 1: The yield of different organic solvents of $L$. pseudotheobromae IBRL OS-64 extract paste.

\begin{tabular}{cccc}
\hline Extracts & Weight $(\mathbf{g} / \mathbf{L})$ & Percentage $(\%)$ & Colour \\
\hline Hexane & $0.01 \pm 0.01$ & 0.69 & colourless \\
Dichloromethane & $0.74 \pm 0.04$ & 52.86 & brownish \\
Ethyl acetate & $0.32 \pm 0.02$ & 22.86 & beige \\
Butanol & $0.13 \pm 0.02$ & 9.29 & yellowish \\
\hline
\end{tabular}

${ }^{\star}$ Data are presented as mean \pm S.D. $(n=3)$.

Table 2: Antibacterial activity of various Lasiodiplodia pseudotheobromae IBRL OS-64 extracts against test bacteria on disk diffusion assays.

\begin{tabular}{lccccc}
\hline Test microorganisms & \multicolumn{5}{c}{ Diameter of inhibition zone $(\mathrm{mm} \pm \mathrm{SD})$} \\
& HEX & \multicolumn{2}{c}{ Fermentative broth } & Drug control \\
\hline Gram-positive bacteria & & & EA & BUT & C \\
B. cereus & - & - & $21.0 \pm 1.0$ & - & $29.3 \pm 1.0$ \\
B. subtilis & - & - & $26.0 \pm 1.0$ & - & $28.7 \pm 1.2$ \\
S. aureus & - & - & $20.4 \pm 0.6$ & - & $31.2 \pm 0.8$ \\
Gram-negative bacteria & - & - & $14.2 \pm 0.3$ & - & $28.4 \pm 1.2$ \\
A. anitratus & - & - & $15.7 \pm 0.6$ & - & $31.3 \pm 0.6$ \\
E. coli & - & $8.6 \pm 0.2$ & $20.1 \pm 0.6$ & - & $28.3 \pm 1.2$ \\
Y. enterocolitica & - &
\end{tabular}

Notes: $\mathrm{HEX}=$ hexane, $\mathrm{DCM}=$ dichloromethane, $\mathrm{EA}=$ ethyl acetate, $\mathrm{BUT}=$ butanol and $\mathrm{C}=$ chloramphenicol. ${ }^{*}$ Data are presented as mean \pm S.D. $(n=3)$.

Table 3: Minimum inhibitory concentration (MIC) and minimum bactericidal concentration (MBC) values of ethyl acetate crude extract against several test bacteria.

\begin{tabular}{ccccc}
\hline Microorganisms & MIC $(\mu \mathrm{g} / \mathrm{ml})$ & MBC $(\mu \mathrm{g} / \mathrm{ml})$ & Ratio $(\mathrm{MBC} / \mathrm{MIC})$ & Conclusion \\
\hline B. cereus & 62.5 & 125 & 2 & Bactericidal \\
B. subtilis & 62.5 & 125 & 2 & Bactericidal \\
S. aureus & 125 & 250 & 2 & Bactericidal \\
A. anitratus & 500 & 1000 & 4 & Bactericidal \\
E. coli & 500 & 2000 & 2 & Bactericidal \\
Y. enterocolitica & 250 & 500 & 4 & Bactericidal \\
\hline
\end{tabular}




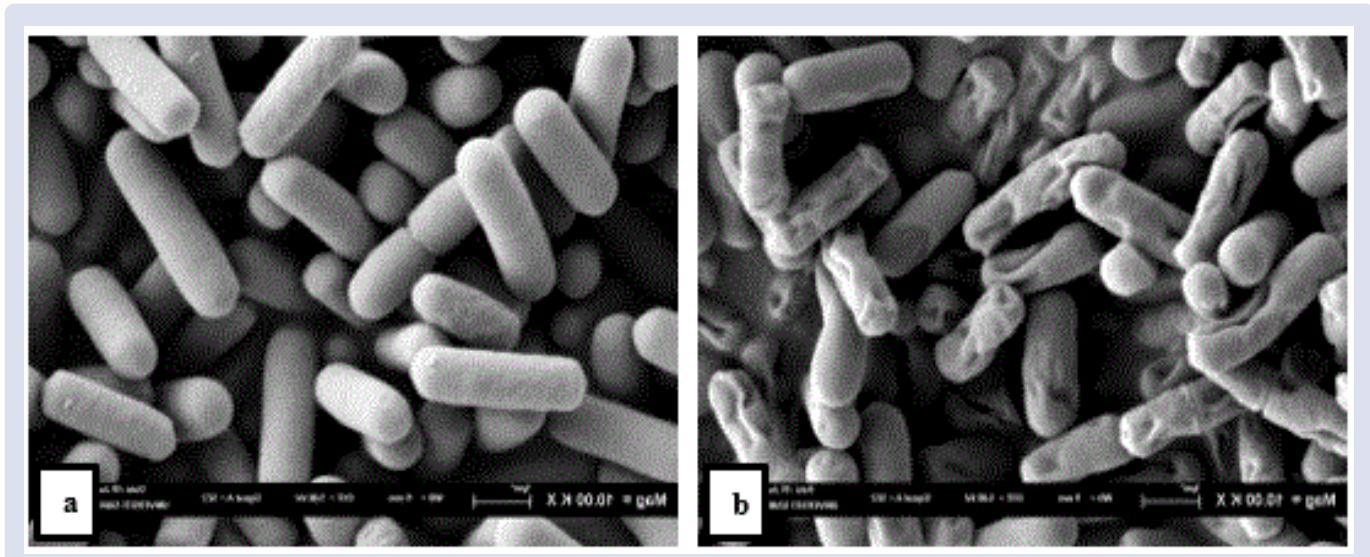

Figure 1: SEM photomicrographs of Bacillus cereus treated with $125 \mu \mathrm{g} / \mathrm{mL}$ of L. pseudotheobromae IBRL OS-64 ethyl acetate extract. (a) non-treated bacterial cells and (b) extract-treated bacterial cells. Scale bars: 100nm.

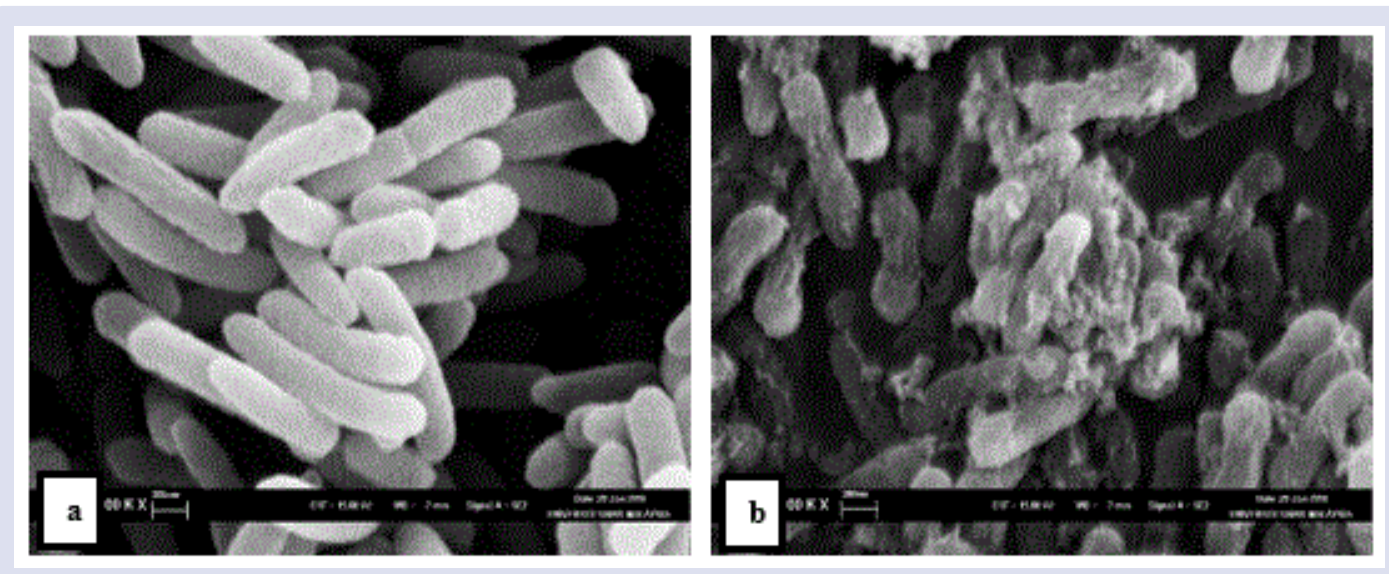

Figure 2: SEM photomicrographs of Yersinia enterocolitica treated with $500 \mu \mathrm{g} / \mathrm{mL}$ of L. pseudotheobromae IBRL OS-64 ethyl acetate extract. (a) non-treated bacterial cells and (b) extract-treated bacterial cells. Scale bars: 100nm.

\section{DISCUSSION}

The choice of solvent for extraction depends on the purpose of studying the extract. ${ }^{3}$ In the present study, the organic solvents with different polarity ranges were selected for extraction to gain the diverse type of bioactive compounds with antibacterial activity. According to $\mathrm{Gu}^{24}$ liquid-liquid extraction including aqueous two-phase and solvent partitioning is very useful procedures in bio-separation. Four types of organic solvents with different polarities were used in this study which was hexane, dichloromethane, ethyl acetate, and butanol. Abarca-Vagas ${ }^{25}$ reported the polarity of the organic solvents used for the extraction process plays a vital role in the efficacy and efficiency of bioactive compounds with pharmacological activities. Hexane is one of the organic solvents that frequently used for extraction and it can dissolve non-polar compounds such as lipid, wax, and lignin. ${ }^{26}$ Meanwhile, dichloromethane and ethyl acetate are used to extract more lipophilic and hydrophilic compounds, respectively. ${ }^{27}$ Besides that, butanol which is more polar organic solvents frequently used for extraction of polar compounds such as flavonoid glycosidase. ${ }^{28,29}$ The liquid-liquid partitioning of ethyl acetate crude paste of $L$. pseudotheobromae IBRL OS-64 revealed that organic solvent, dichloromethane was able to dissolve the highest extract paste with the value of $0.74 \mathrm{~g} / \mathrm{L}$ or $52.86 \%$. Similar observation also reported by Tong $^{30}$ that mentioned dichloromethane gave the highest production of crude extract paste of Penicillium minioluteum ED24 with a value of $1.52 \mathrm{~g} / \mathrm{L}$. Meanwhile, the least yield obtained was the hexane extract with a percentage of 0.69 . The results were in agreement with Mabiki ${ }^{31}$ who stated the extraction process with hexane yielded a low amount of extract. This might be due to the low amount of non-polar compounds in the ethyl acetate crude extract since hexane was mainly to dissolve more non-polar compounds such as wax, lipid, and fat. ${ }^{32}$ Hexane wash also eliminated unwanted metabolites such as fatty acid that not of interest in natural product screening. ${ }^{33}$

According to Franco, ${ }^{34}$ the solubility and polarity of different organic solvents used in the extraction process lead to variation in extraction yield. Begtrup and Larsen ${ }^{35}$ suggested that polar organic solvents including dichloromethane and ethyl acetate are suitable in extracting various bioactive compounds since they are easily evaporated and dried due to low boiling point. The finding also showed that the colorless solution was observed in the hexane extract whereas brown color was observed in the dichloromethane extract. Besides that, the beige and pale yellow color was observed in the ethyl acetate and butanol extracts, respectively. The variation of extract coloration might be due to the capability of the organic solvents to dissolve compounds with different polarities. Due to the close association between endophytes and their host, natural products from fungal endophytes might comprise of a wide variety of bioactive compounds with several chemical classes and functional groups. Wright ${ }^{36}$ postulated that natural products contain a variety of chemical functionalities and the changes in functionality have affected the polarity of the compounds. Therefore, the presence of bioactive compounds in natural products and their activities were affected by the type of organic solvent used for the extraction process. ${ }^{37}$ 
The present results showed that the antibacterial activity of the fungal isolate depends on the efficiency and polarity of the organic solvents. The current study revealed that ethyl acetate, which is the mid-polar solvent is the best organic solvent to extract bioactive compounds with antibacterial potential from the fungal extract paste. The result was in agreement with Avinash ${ }^{38}$ who revealed that ethyl acetate extract of the fungal endophyte, Curvularia lunata demonstrated good activity against all the test pathogenic bacteria including Staphylococcus aureus and Salmonella thypi. According to Tong, ${ }^{39}$ this phenomenon indicates that the antimicrobial compounds were semi-polar and could be extracted using a mid-polar solvent such as ethyl acetate and dichloromethane. However, hexane and butanol extract showed no antibacterial activity against all the test bacteria in the present study. A similar observation was reported by Yenn ${ }^{40}$ whereby none of the antimicrobial compounds were present in hexane fraction (non-polar) and butanol (highly polar) fractions of the endophytic fungal extract, Phomopsis sp. ED2 isolated from Orthosiphon stamineus Benth.

Minimum inhibitory concentration (MIC) and minimum bactericidal concentration (MBC) are frequently used by researchers to confirm resistance and determine the in vitro activity of the new antibiotics as well as determining their MIC's breakpoint. According to Andrew, ${ }^{41}$ MIC is defined as the lowest concentration of a certain antibiotic that will inhibit the growth of a microorganism after an overnight incubation period, whereas the $\mathrm{MBC}$ is the lowest concentration of an antimicrobial that will prevent the growth of a microorganism after subculture onto antibiotic free-media. The present study revealed that the MBC values for all the test bacteria were significantly higher than their MIC's indicating that the crude extract was concentrationdependent in inhibiting the growth of test bacteria. Tong ${ }^{39}$ postulated that the higher MBC value compared to MIC value indicating the extract concentration would have to be increased to significantly kill the microbial cells rather than inhibiting their growth. Furthermore, the crude extract of L. pseudotheobromae IBRL OS-64 was observed to possess a bactericidal effect towards test bacteria due to the low MBC/ MIC ratio. According to Levison, ${ }^{42}$ antimicrobial drugs can be usually considered as bactericidal if the $\mathrm{MBC}$ value, not more four-fold higher than their MIC value. The current results also suggested that the fungal crude extract exhibited a strong antibacterial effect on Gram-positive bacteria as compared to Gram-negative bacteria. These findings are in agreement with the previous study by Marasini ${ }^{43}$ who claimed that MIC values of plant extract against Gram-positive bacteria are significantly low than Gram-negative bacteria. They suggested that this phenomenon may due to the different nature of cell walls for both types of bacteria and the existence of the efflux system in Gram-negative that facilitates them in enhancing their resistant towards antibiotic agents. Generally, the Gram-negative bacteria possess an extra outer membrane that consists of the asymmetric distribution of the lipids with phospholipids and lipopolysaccharide located in the inner and outer leaflets that could act as an additional barrier that restricts the movement of a foreign substance through the cell. ${ }^{44}$ This component is absent in the Gram-positive bacteria, but their cell wall contains lipoteichoic acids (LTA) that are unique and essential structure to the cells. However, the component could be good drug targets to bioactive compounds ${ }^{45}$ and this might explain why the Gram-positive bacteria are more susceptible to the fungal extract compared to Gram-negative bacteria.

SEM photomicrograph's observations were performed to investigate the effects of the crude fungal extract on different bacterial cells and to support the previous result of antibacterial activity after exposing them to the extract. The findings exhibited the antibacterial effects of the ethyl acetate crude extract on both Gram-positive and Gram-negative bacterial cells. There were clear morphological changes with irregular and collapsed cells observed on both bacterial cells after 24 hours of treatment with the fungal extract. This phenomenon could be due to some alterations occurred in the cell membrane permeability or may be leaking in the cell wall. As for Gram-positive bacteria, some cavities and dents were observed on the treated cell. A similar observation reported by Asnani ${ }^{46}$ who studied the morphology of $B$. cereus cells exposed to water and ethyl acetate fraction of Spondias pinnata leaves under SEM. Hartmann ${ }^{47}$ suggested the formation of holes, craters, and dents on the surface of bacterial cells indicated a failure or a mechanism rupture of the cell wall and membrane. The Gram-negative bacteria cells expose to fungal extract showed wrinkled, crumpled or shrunken cell surface and the cells had lost their original rod shape compared to control. There were some holes formed on the cell wall indicated the cell leakage. Similarly, $\mathrm{Fu}^{48}$ demonstrated a Gram-negative bacterium, Y. enterocolitica exposed to endogenous peptide $\beta$-casein 197 showed disorganized cell structures with wrinkled surface upon SEM observation. According to Hyde, ${ }^{49}$ the morphological changes of the bacterial cell treated with antibiotics occur when the antimicrobial agent attacked the cell membrane. The bioactive compound from the extract might target cell surface structure and permeabilized the bacterial membrane and any disruption in cell wall integrity leads to the complete damage of bacterial cells. ${ }^{50}$ Armas $^{51}$ revealed that the morphological alterations of bacterial surface including roughening, blebbing with cellular debris and formation of holes indicated a membrane-damage activity by the antimicrobial compounds. According to Chaparro, ${ }^{52}$ the aggregations and abnormal cell shapes with surface changes might be attributed to the leakage of cellular contents. Besides that, Al-Adham ${ }^{53}$ postulated the crumpled cell and formation of hole may indicate the loss of cellular materials and organelles from the cell cytoplasm that will lead to cell death. Previous studies proposed some mechanisms that might be contributed to the dysfunction of bacteria cells. Guimaraes ${ }^{54}$ reported the changes in the ion channels such as $\mathrm{Na}^{+}$and $\mathrm{K}^{+}$in the cell membrane might increase the permeability of the cell and thus release the vital intracellular constituents. Meanwhile, the bioactive compounds such as $\beta$-lactam able to disrupt the synthesis of peptidoglycan which is the main component of bacterial cell walls and hence, leading to cell death. ${ }^{55}$ Besides that, antibiotics such as chloramphenicol and tetracyclines are able to inhibit protein biosynthesis by targeting the $50 \mathrm{~S}$ or $30 \mathrm{~S}$ subunit of the bacterial ribosome. ${ }^{56}$ However, the mode of action of the ethyl acetate extract of $L$. pseudotheobromae IBRL OS-64 against test bacteria remains unknown but it is believed that the extract may target the bacterial cell wall and ignite some alterations causing collapsed cells and finally led to cell death.

\section{CONCLUSION}

The findings revealed that the ethyl acetate crude extract of $L$. pseudotheobromae IBRL OS-64 has a great potential as an antibacterial agent to treat infectious diseases caused by a range of pathogenic bacteria. The results could form the basis for further studies to develop endophytic fungal extracts as antibiotics and evaluate them against a wide range of bacterial strains.

\section{ACKNOWLEDGMENT}

The authors are grateful to Universiti Sains Malaysia for awarding the RUI research grant scheme (ac: 1001/PBIOLOGI/811326) to support this study.

\section{CONFLICTS OF INTEREST}

\section{None.}

\section{ABBREVIATIONS}

MIC: Minimum inhibitory concentration, MBC: Minimum bactericidal concentration, SEM: Scanning electron microscope, PDA: Potato dextrose agar, NA: Nutrient agar, YES: Yeast extract sucrose, MHA: Muller Hinton agar, MHB: Muller Hinton broth, CFU: Colony 
forming unit, SD: Standard deviation, LTA: Lipoteichoic acids, HEX: Hexane, DCM: Dichloromethane, EA: Ethyl acetate, BUT: Butanol, C: Chloramphenicol.

\section{REFERENCES}

1. Mostafa AA, Al-Askar AA, Almaary KS, Dawoud T.M, Sholkamy EN, Bakri MM Antimicrobial activity of some plant extracts against bacterial strains causing food poisoning diseases. Saudi J Biol Sci. 2017;25(2):361-6. https://doi. org/10.1016/j.sjbs.2017.02.004

2. Adak GK, Long SM, O'Brien SJ. Trends in indigenous foodborne disease and deaths, England and Wales: 1992 to 2000. Gut. 2002;51(6):832-41. https://doi. org/10.1136/gut.51.6.832

3. Darah I, Tong WY, Nor-Afifah S, Nurul-Aili Z, Lim SH. Antimicrobial effects of Caulerpa sertularioides extract on foodborne diarrhea-caused bacteria. Eur Rev Med Pharma Sci. 2014;18:171-8

4. Akinyemi KO, Oluwa OK, Omomigbehin EO. Antimicrobial activity of crude extracts of three medicinal plants used in South-west Nigerian Folk medicine on some foodborne bacterial pathogens. Afr J Trad CAM. 2006;3(4):13-22.

5. Solomakos N, Govaris A, Koidis P, Botsoglou N. The antimicrobial effect of thyme essential oil, nisin and their combination against Escherichia coli O157:H7 in minced beef during refrigerated storage. Meat Sci. 2008;80:159-66. https://doi. org/10.1016/j.meatsci.2007.11.014

6. Wang $Y$, Zhang $S$, Yu J, Zhang $H$, Yuan Z, Sun $Y$, Zhang $L$, Zhu $Y$, Song $H$. An outbreak of Proteus mirabilis food poisoning associated with eating stewed pork balls in brown sauce, Beijing. Food Control. 2010;21:302-5. https://doi. org/10.1016/j.foodcont.2009.06.009

7. Bari Md-L, Hossain MA, Isshiki K, Ukuku D. Behavior of Yersinia enterocolitica in Foods. Journal of Pathogens, Volume 2011, Article ID 420732, 13 pages. https://doi.org/10.4061/2011/420732

8. Tewari A, Abdullah S. Bacillus cereus food poisoning: international and Indian perspective. J Food Sci Technol. 2014;52(5):2500-11. https://doi.org/10.1007/ s13197-014-1344-4

9. Apetroaie-Constantin C, Mikkola R, Andersson MA, Teplova V, Suominen I, Johansson T, Salkinoja-Salonen, M. Bacillus subtilis and B. mojavensis strains connected to food poisoning produce the heat stable toxin amylosin J Appl Microbiol. 2009;106(6):1976-85. https://doi.org/10.1111/j.13652672.2009.04167.x

10. From C, Pukall R, Schumann P, Hormazabal V, Granum PE. (2005). Toxinproducing ability among Bacillus spp. outside the Bacillus cereus group. Appl Environ Microbiol Mar. 2005;71(3):1178-83. https://doi.org/10.1128/ AEM.71.3.1178-1183.2005

11. Brunelle BW, Bearson BL, Bearson SMD, Casey TA. Multidrug-resistant Salmonella enterica SerovarTyphimurium isolates are resistant to antibiotics that influence their swimming and swarming motility. mSphere. 2017;2(6):e0030617. https://doi.org/10.1128/mSphere.00306-17.eCollection

12. Kiessling CR, Cutting JH, Loftis, M, Kiessling WM, Datta AR, Sofos JN. Antimicrobial resistance of food-related Salmonella isolates. J Food Prot, 2002;65(4):603-8. https://doi.org/10.4315/0362-028X-65.4.603

13. Nikaido H. Multidrug resistance in bacteria. Annu Rev Biochem. 2009;78:11946. https://doi.org/10.1146/annurev.biochem.78.082907.145923.

14. Baljeet SY, Simmy G, Ritika Y, Roshanlal Y. Antimicrobial activity of individual and combined extracts of selected spices against some pathogenic and food spoilage microorganisms. Int Food Res J. 2015;22(6):2594-600.

15. Gutierrez J, Barry-Ryan C, Bourke P. Antimicrobial activity of plant essential oils using food model media: Efficacy, synergistic potential and interactions with food components. Food Microbiol. 2009;26(2):142-50. https://doi.org/10.1016/j. fm.2008.10.008. Epub 2008 Nov 1

16. Stone JK, Bacon CW, White JF. An overview of endophytic microbes: Endophytism defined. In: Bacon CW, White JF, Eds., Microbial endophytes, Marcel Dekker, New York, 2000;3-29.

17. Jia M, Chen L, Xin HL, Zheng CJ, Rahman K, Han T, Qin LP. A friendly relationship between endophytic fungi and medicinal plants: A systematic review. Front Microbiol. 2016;7:906. https://doi.org/10.3389/fmicb.2016.00906

18. Kwon J-H, Choi O, Kang B, Lee Y, Park J, Kang D-W, Han I, Kim J. Identification of Lasiodiplodia pseudotheobromae causing mango dieback in Korea. Can J Plant Pathol. 2017;39(2):241-5. https://doi.org/10.1080/07060661.2017.1329231

19. Lu X, Chen G, Li Z, Zhang Y, Wang Z, Rong W, Pei Y, Pan H, Hua H, Bai J. Palmarumycins from the endophytic fungus Lasiodiplodia pseudotheobromae XSZ-3. Helv Chim Acta. 2014;97(9):1289-94 https://doi.org/10.1002/ hlca.201300436

20. Taufiq MMJ, Darah I. Anti-MRSA of ethyl acetate crude extract from Lasiodiplodia pseudotheobromae IBRL OS-64, an endophytic fungus isolated from leaf of Ocimum sanctum Linn. Int J Pharm Pharm Sci. 2018;10(8):50-5. https://doi.org/10.22159/ijpps.2018v10i8.26527
21. Qian C-D, Fu Y-H, Jiang F-S, Xu Z-H, Cheng D-O, Ding B, Gao C-X, Zhi-Shan Ding Z-S. Lasiodiplodia sp. ME4-2, an endophytic fungus from the floral parts of Viscum coloratum, produces indole-3-carboxylic acid and other aromatic metabolites. BMC Microbiol. 2014;14:297. https://doi.org/10.1186/s12866-014-0297-0

22. Taufiq MMJ, Darah I. Antibacterial activity of an endophytic fungus Lasiodiplodia pseudotheobromae IBRL OS-64 residing in leaves of a medicinal herb, Ocimum sanctum Linn. J App Biol Biotech. 2019;7(02):35-41. https://doi.org/10.7324/ JABB.2019.70207

23. National Committee for Clinical Laboratory Standards (NCCLS). Performance Standards for Antimicrobial Disk and Dilution Susceptibility Testing; Fourteenth Informational Supplement NCCLS documents M100-S14. 2004. Wayne, Pennsylvania, USA.

24. Gu T. (2000). Liquid-liquid partitioning methods for bioseparations. Sep Sci Technol. 2000;2:329-64. https://doi.org/10.1016/S0149-6395(00)80054-9

25. Abarca-Vargas R, Malacara CFP, Petricevich VL. Characterization of chemical compounds with antioxidant and cytotoxic activities in Bougainvillea $\mathrm{x}$ buttiana Holttum and Standl, (var. Rose) extracts. Antioxidants. 2016;5:45. https://doi. org/10.3390/antiox8080264

26. Houghton PJ, Raman A. Laboratory handbook for the fractionation of natural extracts. New York: Chapman and Hall, 1998;199.

27. Sasidharan S, Chen Y, Saravanan D, Sundram KM, Latha LY. Extraction, isolation and characterization of bioactive compounds from plants' extracts. Afr J Trad CAM. 2011;8(1):1-10.

28. Nwabueze TU, Okocha KS. Extraction performances of polar and non-polar solvents on the physical and chemical indices of African breadfruit (Treculia africana) seed oil. Afr J Food Sci. 2008;2:119-25.

29. Hossain MA, Al-Raqmi KAS, Al-Mijizy ZH, Weli AM, Al-Riyami Q. Study of tota phenol, flavonoids contents and phytochemical screening of various leaves crude extracts of locally grown Thymus vulgaris. Asian Pac JTrop Biomedicine. 2013;3(9):705-10. https://doi.org/10.1016/S2221-1691(13)60142-2

30. Tong WY. Antimicrobial activity of two endophytic fungi, Phomopsis sp. ED2. And Penicillium minioletum ED24 isolated from Orthosiphon stamineus Benth and their potential antimicrobial compounds. PhD Dissertation. Universiti Sains Malaysia, Pulau Pinang. 2014;159.

31. Mabiki FP, Magadula JJ, Mdegela RH, Mosha RD. Optimization of extraction conditions and phytochemical screening of root extract of Synadenium glaucescens Pax. Int J Chem 2013;5(4):103-12. https://doi.org/10.5539/ijc. v5n4p103

32. Sicaire A, Vian M, Fine F, Joffre F, Carre P, Tostain S, Chemat F. Alternative biobased solvents for extraction of fat and oils: solubility prediction, global yield, extraction kinetics, chemical composition and cost of manufacturing. Int $\mathrm{J}$ Mol Sci. 2015;16(4):8430-53. https://doi.org/10.3390/ijms16048430

33. VanderMolen KM, Raja HA, El-ElimatT, Oberlies NH. Evaluation of culture media for the production of secondary metabolites in a natural products screening program. AMB Express. 2013;3:71. https://doi.org/10.1186/2191-0855-3-71

34. Franco D, Sineiro J, Rubilar $M$, Sanchez $M$, Jerez $M$, Pinelo $M$, Nunez MJ Phenols from plant materials: extraction and antioxidant power. Elec J Env Agricult Food Chem. 2008;7:3210-6.

35. Begtrup M, Larsen P. Alkylation, acylation and silylation of azoles. Acta Chem Scand. 1990;44:1050-7. https://doi.org/10.3891/acta.chem.scand.44-1050

36. Wright AE. Isolation of marine natural products. Methods Biotechnol. 1998;4:365-408. https://doi.org/10.1007/978-1-59259-256-2_13

37. Kandasamy M, Arunachalam KD. Evaluation of In vivo antibacterial property of seaweeds of South-East coast of India. Afr J Biotechnol. 2008;7:1958-61.

38. Avinash KS, Ashwini HS, Ramesh Babu HN, Krishnamurthy YL. Antimicrobial potential of crude extract of Curvularia lunata, an endophytic fungi isolated from Cymbopogon caesius. J Mycol. 2015;185821:4. https://doi. org/10.1155/2015/185821

39. Tong WY, Nurul Zaadah J, Nurhaida, Tan WN, Melati K, Latiffah Z, Darah I. Antimicrobial activity of Phomopsis sp. ED2 residing in medicinal plant Orthosiphon stamineus Benth. Annu Res Rev Biol. 2014;4(9):1490-501.

40. Yenn TW, Ibrahim D, Zakaria L. Antimicrobial activity of Phomopsis sp. ED2, an endophytic fungus isolated from Orthosiphon stamineus Benth. Proceedings of The 2nd Annual International Conference Syiah Kuala University 2012 \& The 8th IMT-GT Uninet Biosciences Conference Banda Aceh, 22-24 November 2012.

41. Andrew JM. Determination of minimum inhibitory concentrations. J Antimicrob Chemother. 2001;48(1):5-16. https://doi.org/10.1093/jac/48.suppl_1.5

42. Levison ME. Pharmacodynamics of antibacterial drugs. Infect Dis North Am. 2000;14:281-91. https://doi.org/10.1016/j.idc.2009.06.008

43. Marasini BP, Baral P, Aryal P, Ghimire KR, Neupane S, Dahal N, Singh A Ghimire L, Shrestha K. Evaluation of antibacterial activity of some traditionally used medicinal plants against human pathogenic bacteria. BioMed Research International, 2015;265425. https://doi.org/10.1155/2015/265425

44. Pages JM, James CE, Winterhalter M. The porin and the permeating antibiotic: A selective diffusion barrier in Gram-negative bacteria. Nat Rev Microbiol. 2008;6:893-903. https://doi.org/10.1038/nrmicro1994 
45. Pasquina LW, Santa Maria JP, Walker S. Teichoic acid biosynthesis as an antibiotic agent. Curr Opin Microbiol. 2013;16(5):531-7. https://doi.org/10.1016/j. mib.2013.06.014

46. Asnani, Rahayu WP, Jenie BSL, Yuliana ND. Antibacterial stability of Spondias pinnata (L.f.) Kurz leaves extract and its mechanism. Malaysian J Microbiol. 2018;14(5):393-400. https://doi.org/10.21161/mjm.112117

47. Hartmann M, Berditsch M, Hawecker J, Ardakani MF, Gerthsen D, Ulrich AS. Damage of the bacterial cell envelope by antimicrobial peptides gramicidin $\mathrm{S}$ and PGLa as revealed by transmission and scanning electron microscopy. Antimicrob Agents Chemother. 2010:54(8):3132-42. https://doi.org/10.1128/ AAC.00124-10

48. Fu Y, Ji C, Chen $X$ Cui $X$, Wang $X$, Feng J, Li Y, Oin R, Guo X Investigation into the antimicrobial action and mechanism of a novel endogenous peptide $\beta$-casein 197 from human milk. AMB Express. 2017;7:119. https://doi. org/10.1186/s13568-017-0409-y

49. Hyde AJ, Parisot J, McNichol A, Bonev BB. Nisin-induced changes in Bacillus morphology suggest a paradigm of antibiotic action. Proc Natl Acad Sci USA 2006;103:19896-901. https://doi.org/10.1073/pnas.0608373104

50. Darah I, Lim SH, Nithianantham K. Effects of methanol extract of Wedelia chinensis Osbeck (Asteraceae) leaves against pathogenic bacteria with emphasize on Bacillus cereus. Indian J Pharm Sci. 2013;75(5):533-9.
51. Armas F, Pacor S, Ferrari E, Guida F, Pertinhez TA, Romani AA, Scocchi M, Benincasa M. (2019) Design, antimicrobial activity and mechanism of action of Arg-rich ultra-short cationic lipopeptides. PLoS ONE. 2019;14(2):e0212447. https://doi.org/10.1371/journal.pone.0212447

52. Chaparro SCV, Salguero JTV, Baquero DAM, Perez JER. Effect of polyvalence on the antibacterial activity of a synthetic peptide derived from bovine lactoferricin against healthcare-associated infectious pathogens. Hindawi: BioMed Res Int. 2018; 5252891:12. https://doi.org/10.1155/2018/5252891

53. Al-Adham IS, Dinning AJ, Eastwood IM, Austin P, Collier PJ. Cell membrane effects of some common biocides. J Ind Microbiol Biotechnol. 1998;21:6-10. https://doi.org/10.1038/sj.jim.2900554

54. Guimaraes AC, Meireles LM, Lemos MF, Guimaraes M, Endringer DC, Fronza M, Scherer R. Antibacterial activity of terpenes and terpenoids present in essential oils. Molecules. 2019;24(13):2471. https://doi.org/10.3390/molecules24132471

55. Egorov AM, Ulyashova MM, Rubtsova MY. Bacterial Enzymes and Antibiotic Resistance. Acta Naturae. 2018;10(4):33-48.

56. Kapoor G, Saigal S, Elongavan A. Action and resistance mechanisms of antibiotics: A guide for clinicians. J Anaesthesiol Clin Pharmacol. 2017;33(3):3005. https://doi.org/10.4103/joacp.JOACP_349_15 


\section{GRAPHICAL ABSTRACT}

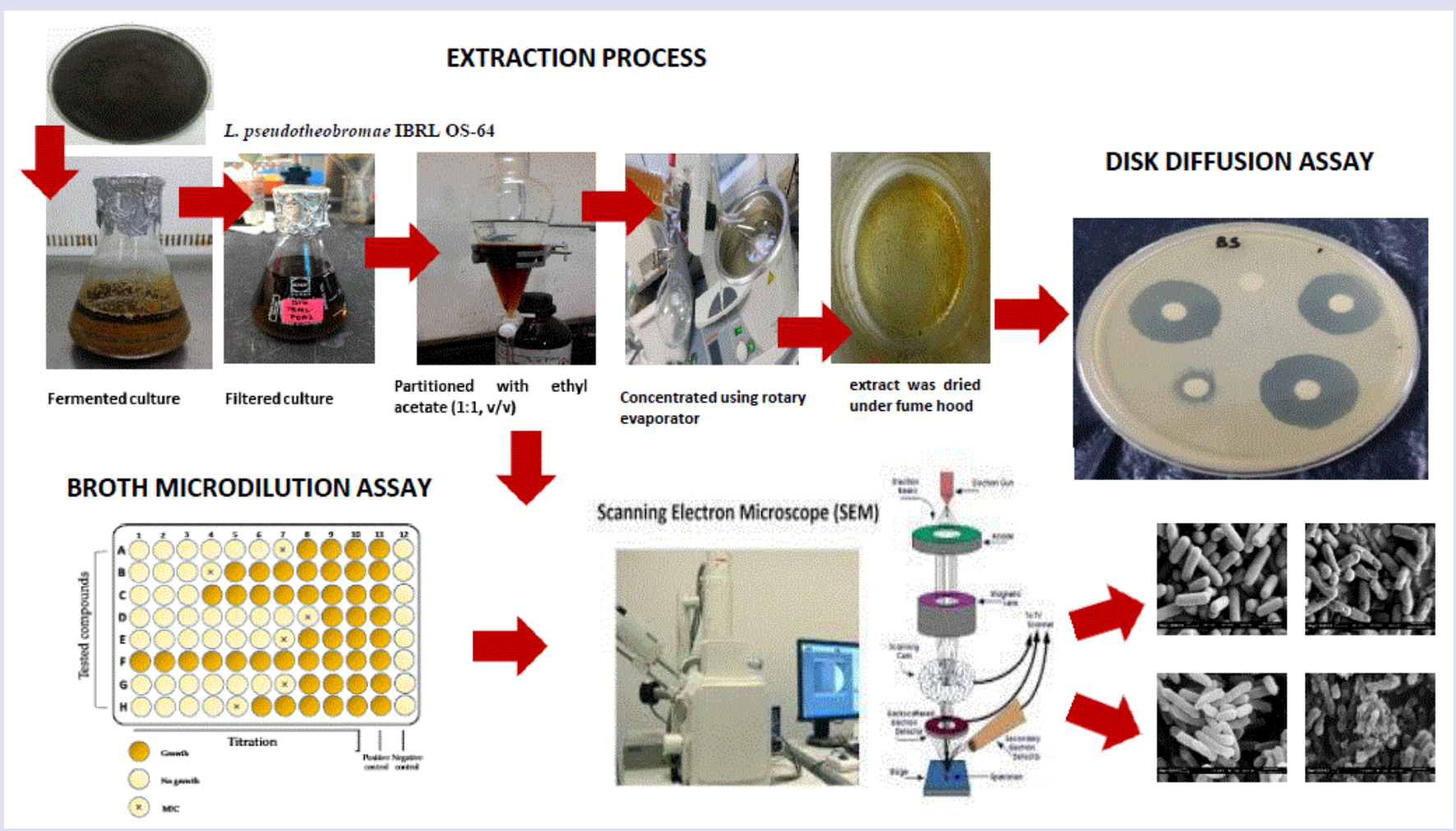

\section{ABOUT AUTHORS}
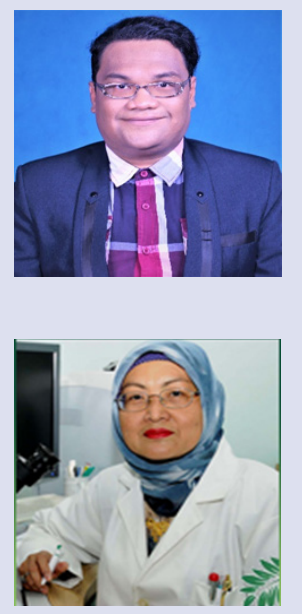

Mohd Taufiq Mat Jalil graduated from the Universiti Sains Malaysia, Penang, Malaysia with a degree in Microbiology and later received a Master's degree in Industrial Microbiology and followed by a Ph.D.'s degree in Microbial Biotechnology from the same University. His fields of research are Biology, Enzymology, Enzyme and Fermentation Technology, Bacteriology, Microbial Biotechnology, Microbiology, Microbial Secondary Metabolites, Biotechnology and Biostatistics. He is currently working as a Researcher at Industrial Biotechnology Research Laboratory, School of Biological Sciences, Universiti Sains Malaysia, Penang, Malaysia.

Darah Ibrahim is a Professor of Microbiology at the School of Biological Sciences, Universiti Sains Malaysia, Penang, Malaysia. She obtained her B. Sc. Hons from the Universiti Kebangsaan Malaysia in 1979; M. Sc. (Medical Sciences) from the University of Glasgow, Scotland; PhD from the Universiti Sains Malaysia in 1997. Her fields of research are fermentation and enzyme technology, microbial natural products, medical microbiology and industrial microbiology.

Cite this article: Taufiq MMJ, Darah I. Biological Activity of Lasiodiplodia pseudotheobromae IBRL OS-64 Extracts, an Endophytic Fungus Isolated from Medicinal Herb, Ocimum sanctum Against Foodborne Diarrhea-Caused Bacteria. Pharmacogn J. 2020;12(4):897-904. 